\title{
THE SERAMBI OF NEGERI SEMBILAN TRADITIONAL MALAY HOUSE AS A MULTIFUNGSIONAL SPACE - ROLE IN CUSTOM (ADAT).
}

\section{SERAMBI RUMAH TRADISIONAL MELAYU NEGERI SEMBILAN SEBAGAI RUANG MULTIFUNGSI PERANAN DALAM ADAT.}

\author{
Siti Fatimah Tuzzahrah Binti Hj Abd Latif , Kamarul Afizi Kosman \\ Fakulti Kejuruteraan \& Alam Bina, Universiti Kebangsaan Malaysia (UKM), 43650, Bangi \\ E-mails: aakee.n9@gmail.com,kamarulafizi@ukm.edu.my
}

\begin{abstract}
Nowadays, Malays residential design has been influenced by modern design that has ignored the wellness factor thus inviting the difficulties and inconvenience to residents. Reinterpretated the concept of space in Malay house must be pursued to enhance the understanding against the important of space function for a lesson and seen their suitability to applied in nowdays design reflected to Malaysian culture and identity. This article will focus on serambi space in Negeri Sembilan traditional Malay house by describing deeply the diversity function of serambi through conducting research on role of serambi space during the execution of Adat Perpatih activities. The methodology used for these qualitative study is analysis of previous studies, deeply observation and narrative studies including the exclusive interview with the customary chiefs and expert scholars of Adat Perpatih and the architecture of Negeri Sembilan traditional Malay house. Several respondents were interviewed and the data obtained were analysed by using thematic analysis. Four themes have been developed which is serambi as a discussion space, ritual space, social space and educated inhabitant manners. Themes discussion will describe the diversity function of serambi in Negeri Sembilan Malay house towards antropologies perspective. Result of the study show the serambi space designed by previous Malay community has demonstrated extensive functionality to cover the needs of inhabitant daily life, customs practiced and filling the Islamic demand.
\end{abstract}

Keywords: Negeri Sembilan Traditional Malay House, serambi, Perpatih Custom, culture, syarak.

\begin{abstract}
ABSTRAK
Pada masa kini, rekabentuk rumah kediaman orang Melayu telah dipengaruhi oleh rekabentuk moden yang telah mengabaikan banyak faktor kesejahteraan sehingga mengundang kesukaran dan ketidakselesaan kepada penghuni rumah kediaman. Penafsiran semula terhadap konsep ruang rumah Melayu perlu dilaksana bagi meningkat kefahaman masyarakat tentang kepentingan kewujudan ruang yang berfungsi untuk diambil pengajaran dan dilihat kesesuaian untuk diterap ke dalam rekabentuk rumah yang mencerminkan budaya dan identiti negara. Artikel ini akan memfokuskan terhadap seni bina ruang serambi rumah tradisional Melayu di Negeri Sembilan dengan menghuraikan kepelbagaian fungsi ruang serambi rumah Negeri Sembilan melalui penelitian terhadap peranan ruang serambi sewaktu pelaksanaan aktiviti Adat Perpatih di ruang tersebut. Metodologi kajian yang digunakan adalah gabungan beberapa kaedah penyelidikan kualitatif iaitu penganalisaan kajian lepas, pemerhatian dan kajian naratif iaitu temubual eksklusif bersama pembesar-pembesar adat dan pakar ilmuan berkenaan seni bina dan Adat Perpatih di Negeri Sembilan. Beberapa orang responden telah ditemubual dan kesemua data yang diperoleh dianalisa menggunakan analisis tema. Empat tema telah dibangunkan iaitu ruang serambi sebagai ruang perbincangan adat, ruang ritual adat, ruang sosial dan ruang pendidikan adab. Perbincangan tema telah menghurai kepelbagaian fungsi ruang serambi daripada perspektif antropologi. Hasil daripada kajian menunjukkan rekabentuk ruang serambi rumah Negeri Sembilan telah mempamerkan fungsi yang menyeluruh mencakupi keperluan budaya kehidupan seharian penghuni, pegangan adat dan tuntutan syarak.
\end{abstract}

Kata kunci: Rumah Tradisional Melayu Negeri Sembilan, serambi, Adat Perpatih, budaya, syarak. 


\section{PENGENALAN}

Seni bina Melayu tradisi, khususnya seni bina rumah kediaman merupakan sebuah contoh seni bina yang mencakupi pelbagai aspek bagi menangani keperluan kehidupan masyarakat pada zaman dahulu. Penafsiran semula terhadap kehebatan seni bina rumah Melayu tradisi perlu dilaksanakan bagi membina kefahaman yang holistik kepada masyarakat supaya mengambil pengajaran serta menyumbangkan idea kepada pereka pada masa kini untuk menghasilkan produk yang setanding dengan kehebatan rekaan masyarakat Melayu terdahulu dalam menghasilkan sebuah seni bina yang unik, hebat dan mampu bertahan sehingga ke hari ini. Pemahaman terhadap seni bina Melayu di Malaysia perlu bermula dengan pemahaman masyarakat terhadap elemen yang terkandung di dalam seni bina tersebut (Afizi \& Lukman, 2007). Penafsiran semula elemenelemen yang terkandung dalam seni bina Melayu merupakan salah satu pendekatan yang telah diperkenalkan ke arah pengecaman dan pengenalan kepada identity seni bina Negara (Afizi. K, 2009; M. Surat et. Al, 2009). Salah satu elemen yang terpenting dalam pembentukan sebuah seni bina adalah konsep ruang. Tidak memahami konsep ruang, bermaksud seni bina tidak dapat berfungsi dengan baik. Ruang-ruang rumah tradisional Melayu terbentuk bagi menampung aktiviti manusia dengan mengambil kira perkaitan dengan faktor persekitaran, adat, budaya, agama, sosial dan ekonomi penghuni (Abdul Halim Nasir \& Wan Hashim Wan Teh 1997). Pada masa kini, rekabentuk rumah kediaman orang Melayu telah dipengaruhi oleh rekabentuk moden yang telah mengabaikan banyak faktor kesejahteraan di dalam rekabentuk ruang sehingga mengundang kesukaran dan ketidakselesaan kepada penghuni rumah kediaman (Ismail et Al, 2013; M.S. Surat et. Al, 2012). Oleh itu, penafsiran semula terhadap konsep ruang rumah Melayu perlu dilaksanakan bagi meningkatkan kefahaman masyarakat akan kepentingan kewujudan ruang yang berfungsi untuk diambil pengajaran dan dilihat kesesuaiannya untuk diterapkan ke dalam rekabentuk rumah kediaman yang mencerminkan budaya dan identiti negara. Artikel ini akan memfokuskan perbincangan berkenaan peranan dan fungsi ruang serambi rumah tradisional Melayu Negeri Sembilan sewaktu menjalankan aktiviti adat yang bertujuan untuk memberi gambaran yang jelas bagaimana ruang ini berfungsi dalam kehidupan masyarakat adat di Negeri Sembilan terutama ketika berlangsungnya aktiviti adat. Berdasarkan pemerhatian penulis, telah banyak kajian yang menyentuh berkenaan aspek fizikal ruang serambi diperbahaskan oleh pengkaji terdahulu. Walaubagaimanapun, penelitian yang mendalam terhadap fungsi dan peranan ruang serambi dari sudut pandang antropologi seperti amalan adat dan budaya hidup penghuni amat jarang diketengahkan sedangkan faktor tersebut memainkan peranan yang penting terhadap penghasilan rekabentuk. Kekurangan kajian serta penerbitan mengenai fungsi serambi dari sudut antropologi telah mewujudkan pemahaman singkat masyarakat terhadap ruang kepada sudut fizikal sahaja. Kewujudan beberapa zon di ruang serambi hanya dikaitkan dengan fungsi asas terhadap pelaksanaan adat tertentu. Pengkaji atau pembaca tidak dapat membayangkan apatah lagi memahami bagaimana adat tersebut berlangsung di dalam ruang. Perbincangan yang dibuat juga secara tidak langsung telah menghurai kepelbagaian fungsi ruang serambi yang telah dicipta oleh masyarakat Adat Perpatih di dalam ruang yang terhad. Penulisan artikel ini, diharap dapat mewujudkan pemahaman yang lebih baik kepada masyarakat luar terutama kepada golongan profesional mengenai kehebatan seni bina, nilai budaya serta fungsi kewujudan ruang serambi pada rekabentuk rumah tradisional Melayu di Negeri Sembilan untuk disuai- padankan dengan rekabentuk moden pada masa kini bagi menghasilkan seni bina yang mencerminkan identiti kebangsaan.

\section{OJEKTIF DAN METODOLOGI}

Bertitik tolak daripada isu dan persoalan kajian, objektif penulisan artikel ini adalah untuk mengenalpasti peranan ruang serambi rumah tradisional Melayu Negeri Sembilan di dalam perlaksanaan aktiviti Adat Perpatih. Kajian yang dijalankan adalah menggunakan kaedah penyelidikan kualitatif menerusi gabungan diantara kajian naratif, pemerhatian dan penganalisaan kajian lepas. Kajian naratif dilaksanakan dengan merekod data berkaitan perlaksanaan beberapa amalan adat di dalam ruang serambi melalui perkongsian pengalaman daripada beberapa orang responden terpilih yang terdiri daripada pakarpakar adat dan pembesar-pembesar adat di daerah Jempol dan Kuala Pilah, Negeri Sembilan. Temubual eksklusif adalah meliputi tatacara perlaksanaan adat, aturan dan dekorasi ruang serta peralatan adat yang diguna sewaktu mendirikan adat di dalam ruang serambi. Kajian naratif digunakan untuk memahami atau mengkaji bagaimana seseorang individu membina makna dalam kehidupan mereka berdasarkan penceritaan pengalaman diri. Kajian ini memberi tumpuan terhadap makna yang ditafsir oleh responden berdasarkan peristiwa-peristiwa yang berlaku dan dialami dalam kehidupan mereka (Creswell, 2009). Pemilihan responden kajian adalah berdasarkan kepakaran dan pengetahuan yang tinggi terhadap amalan Adat Perpatih dalam 
kehidupan. Temubual dilaksanakan secara berperingkat dalam tempoh 4 bulan secara berbengkel bersama-sama responden. Perlaksanaan bengkel Adat Perpatih adalah sebagai usaha pengkaji bagi mendapatkan data-data yang sahih tanpa keraguan yang dipersetujui bersama-sama oleh semua reponden berkaitan perlaksanaan amalan Adat Perpatih di dalam ruang serambi. Temubual dilaksana dalam persekitaran yang kondusif bagi memberi keselesaan kepada reponden bercerita berkenaan pengalaman diri. Data yang diperoleh adalah data primer berbentuk rakaman audiografi, lakaran dan catatan pengalaman responden.

Selain itu, data kajian juga diperoleh menerusi kaedah pemerhatian secara mendalam terhadap perlaksanaan aktiviti adat yang berlangsung di ruang serambi. Pemerhatian dilaksanakan melalui dua kaedah iaitu pemerhatian secara terus iaitu pengkaji telah menyertai aktiviti adat dan budaya tersebut dan juga melalui pengamatan terhadap rakaman video dokumentari perlaksanaan adat yang diperolehi sumbernya melalui pihak Lembaga Muzium Negeri Sembilan dan aplikasi di alam maya bagi acara adat yang tidak sempat disertai oleh pengkaji berikutan kekangan yang dihadapi sewaktu menjalankan kajian. Data yang diperolehi melalui kaedah pemerhatian akan bertindak sebagai elemen sokongan terhadap data yang diperolehi melalui kajian Naratif yang telah dilaksanakan.

Dapatan yang diperolehi dianalisis menggunakan analisis tematik dan seterusnya penyelidik membangunkan kod tema untuk diperbincangkan. Empat tema telah telah dikenalpasti bagi menghuraikan peranan ruang serambi dalam perlaksanaan Adat Perpatih iaitu sebagai ruang perbincangan adat, ruang ritual adat, ruang sosial dan ruang pendidikan adab. Perbincangan tema menghurai kepelbagaian fungsi ruang serambi bagi rumah Melayu tradisional di Negeri Sembilan sewaktu mendirikan adat.

\section{SENI BINA SERAMBI RUMAH SENI BINA SERAMBI RUMAH SEMBILAN. (RTMN9).}

Serambi rumah Melayu boleh didefinasikan sebagai sebuah ruang yang bersifat terbuka,luas dan memanjang yang berada di kedudukan paling hadapan pada rekabentuk rumah tradisional Melayu (Idrus 1996). Ruang serambi kebiasaannya akan dihias, dijaga dan dirapi sebaik mungkin kerana dianggap sebagai wajah pada sesebuah rumah (Salleh, 1982). Ruang serambi dikenali sebagai 'selasar' di Terengganu dan 'sengkuap' di Melaka. Ruang ini direkabentuk sebagai ruang multifungsi oleh masyarakat Melayu terdahulu bagi memenuhi keperluan budaya dan kehidupan seharian. Kebijaksanaan masyarakat terdahulu dalam merekabentuk rumah kediaman jelas terpancar apabila mampu mempelbagaikan aktiviti budaya di dalam sebuah ruang yang terhad. Pada dasarnya, serambi rumah Melayu berfungsi sebagai ruang menyambut dan meraikan tetamu, ruang makan keluarga, tempat beribadat dan beristirehat bagi anak dan tetamu lelaki dalam kehidupan seharian penghuni (Chen, Ariffin \& Wang, 2008; Zahra K.Z \& Sayedah M.T, 2016). Walaubagaimana-pun, ruang ini turut memainkan peranan yang penting dalam perlaksanaan adat istiadat terutama pada masyarakat yang berpegang teguh kepada amalan adat.

Di Negeri Sembilan, ruang serambi memainkan peranan yang besar dalam perlaksanaan adat bermula dari seseorang bayi itu dilahirkan, membesar sebagai kanak-kanak, meningkat remaja, menginjak dewasa, berkahwin, memimpin adat sehinggalah menghembuskan nafas yang terakhir. Penggunaan ruang serambi RTMN9 adalah didominasi oleh kaum lelaki manakala ruang rumah ibu dan dapur pula adalah untuk kaum wanita (Masri, 2016). Setiap zon yang wujud di ruang serambi rumah tidak direka dengan sia-sia malahan dijadikan ruang bagi memenuhi keperluan adat dan kehidupan seharian penghuninya (Hardono.S et. Al, 2014). Ruang ini mempunyai fungsi terberat dalam perlaksanaan adat berbanding ruang-ruang lain selaras dengan tanggungjawab besar yang perlu dipikul oleh kaum lelaki terutamanya dalam hal memimpin adat. Ruang serambi RTMN9 mampu bertindak sebagai sebuah ruang yang formal dan tidak formal bergantung kepada aktiviti yang berlangsung di dalam ruang. Serambi akan bertindak sebagai ruang formal apabila berlangsung acara adat manakala sebagai ruang tidak formal untuk kegunaan harian penghuni (Idrus 1996).

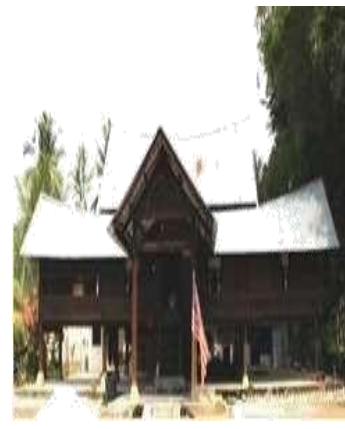

$1 \mathrm{a}$

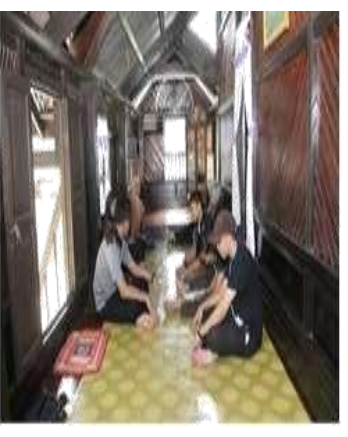

$1 b$
Gambar 1a: Serambi rumah tradisional Melayu Negeri Sembilan.

Gambar 1b: Ruang dalam serambi RTMN9 (Sumber: KAWANS, Politeknik Port Dickson) 
Rekabentuk ruang dalam serambi RTMN9 adalah berbentuk pelan terbuka dimana tiada sekatan di bina di dalam ruang. Ruang serambi dibina memanjang secara horizontal dan terbahagi kepada 3 zon utama iaitu bahagian pangkal, tengah dan hujung serambi. Ketigatiga zon ini mempunyai fungsi yang aktif dan peranan yang berbeza-beza sewaktu berlangsungnya aktiviti adat di ruang tersebut (Nafida, 1999). Bahagian pangkal serambi adalah bahagian yang paling hampir dengan tangga masuk iaitu di bahagian hilir manakala hujung serambi adalah yang paling jauh, iaitu di bahagian hulu. Aras lantai di bahagian serambi hujung kebiasaanya ditinggikan sedikit daripada lantai zon lain. Serambi tengah pula adalah ruang perantara di antara serambi pangkal dan serambi hujung. Masyarakat Melayu terdahulu telah menggunakan arah aliran air sungai sebagai panduan mendirikan rumah kediaman
(Rahman, 2000). Menurut Dato' Maharajasetia Anuar, pembesar adat Luak Jempol, rumahrumah tradisional kebanyakannya pada peringkat awal telah dibina di tepian sungai memandangkan jalan air merupakan jalan pengankutan utama selain daripada jalan darat pada ketika itu. Perantau-perantau Minangkabau yang berhijrah ke Negeri Sembilan telah menyusur sungai dari bahagian hilir ke hulu untuk mencari kawasan yang bersesuaian untuk membina penempatan. Mereka mendirikan rumah kediaman berpandukan kedudukan aliran sungai dengan kedudukan pangkal rumah di bahagian hilir. Oleh itu, kedudukan tangga dan pintu masuk utama RTMN9 direka di bahagian pangkal serambi bagi memudahkan mereka menuju ke dalam rumah setelah turun dari sampan atau perahu,

Rajah 1: Pelan lantai Rumah tradisional Melayu Negeri Sembilan. (Sumber: Penulis)

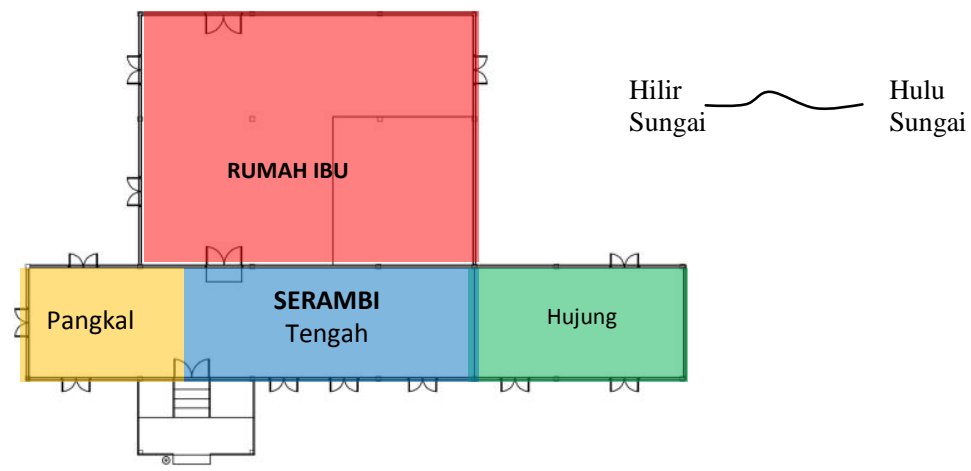

Saiz ruang serambi dibina berdasarkan ukuran lelaki Melayu yang menggunakan ruang tersebut. Lebar purata serambi rumah Negeri Sembilan ialah sekitar 2.2 meter dan jika dirujuk kepada ketinggian purata lelaki Melayu, iaitu 1.7 meter, maka kelebaran ruang tersebut adalah sangat sesuai dengan saiz ketinggian anak-anak bujang yang tidur secara melintang di ruang pangkal serambi (Idrus, 1996). Dengan kelebaran tersebut, maka masih ada sedikit ruang di bahagian kaki mereka untuk tujuan laluan sekiranya hendak bergerak di dalam ruang. Menurut Dato' Shahbandar Hj Ali Bin Naam, pembesar adat Luak Jempol, melalui temubual yang telah dilaksanakan, beliau menyatakan tiada ketetapan dibuat bagi menentukan ukuran panjang ruang serambi RTMN9 seperti ukuran lebar ruang. Ukuran panjang ruang adalah bergantung kepada kemampuan ekonomi pemilik rumah. Oleh itu, masyarakat Negeri Sembilan bebas menentukan saiz rumah mereka mengikut kemampuan mereka. Ukuran orang Melayu ketika menjalankan aktiviti adat istiadat di dalam ruang turut diambil kira dalam peringkat merekabentuk ruang. Serambi rumah Tiang 12 mampu memuatkan enam buah jambar (dulang) ketika berlangsungnya majlis kenduri. Dengan perkiraan sebuah jambar boleh menampung seramai 4 orang untuk makan, maka ruang tersebut mampu menampung sekitar 24 orang dalam sesuatu masa ketika berlangsungnya majlis kenduri (Idrus, 1996; Chen, Ariffin, \& Wang, 2008). Rekabentuk ruang serambi RTMN9 mengutamakan keselesaan penghuni ruang. Penggunaan elemen rekabentuk seperti bendul yang dipasang pada bahagian bawah dinding ruang serambi yang berkepil dengan ruang rumah ibu adalah bertujuan memberi keselesaan kepada penghuni menjalankan aktiviti di dalam ruang selain bertindak sebagai elemen dekorasi. Bendul dijadikan tempat bersandar bagi tetamu yang duduk menghadap ke arah ke arah luar rumah manakala tetamu yang duduk menghadap ke arah dalam rumah pula akan menjadikan dinding ruang serambi tempat bersandar. Bendul juga dipasang pada bahagian bawah pintu, sebagai elemen sekatan kepada tetamu yang datang agar tidak gopoh menuju ke dalam ruang serambi. Pemasangan elemen rekabentuk ini memerlukan tetamu untuk berhenti seketika di kedudukan anak tangga yang terakhir sebelum melangkah secara perlahan-lahan masuk ke ruang dalam rumah. 


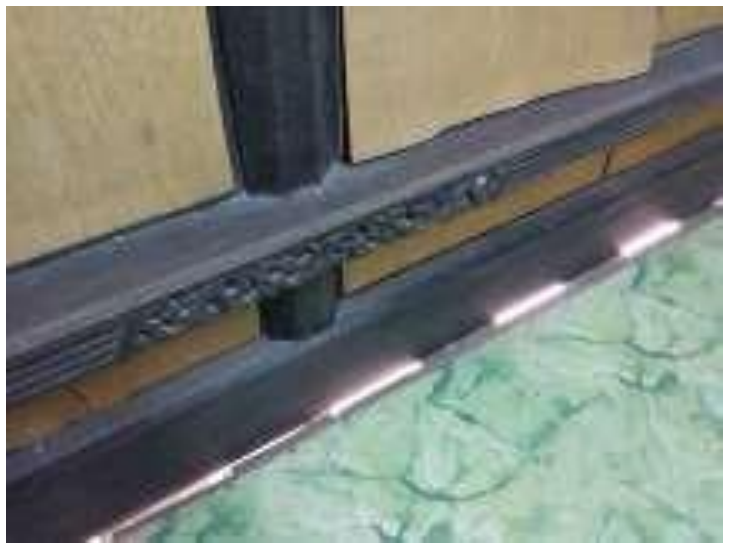

$2 \mathrm{a}$

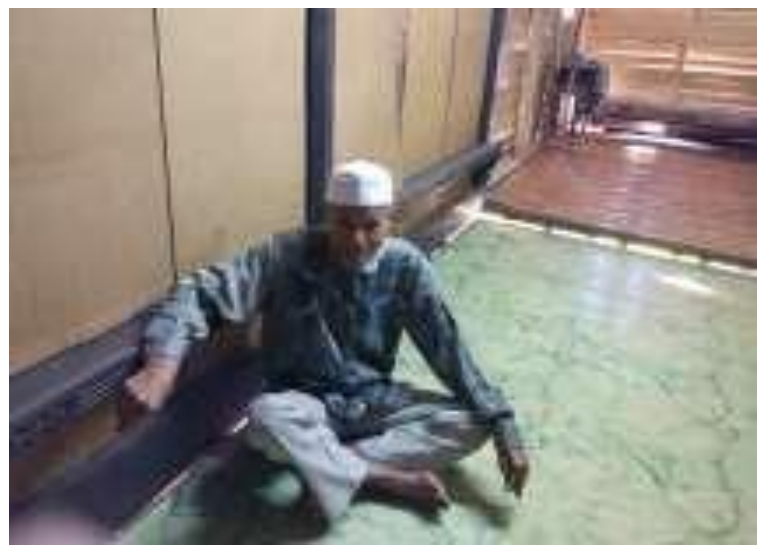

$2 b$

Gambar 2a dan 2b: Elemen bendul pada dinding ruang serambi RTMN9. (Sumber: Penulis)

Peringkat awal rekabentuk ruang serambi RTMN9 adalah berbentuk terbuka, tidak berdinding atau berdinding separuh tanpa penggunaan elemen tingkap. Namun dengan peningkatan ekonomi masyarakat, ruang tersebut kemudiannya telah direkabentuk berdinding penuh. Walaubagaimanapun ciri keterbukaan masih dikekalkan dengan rekaan tingkap yang banyak bagi melancarkan peredaran udara keluar masuk ke dalam ruang serambi bagi tujuan kenyamanan. Selain tingkap yang banyak, peranan pintu secara tersirat adalah membantu kelancaran udara (Zin et. Al, 2012). Terdapat dua pintu dibina pada ruang serambi rumah iaitu pintu masuk utama yang menjadi penghubung di antara alam luar dan penghuni ruang dan pintu menuju ke ruang rumah ibu. Ketinggian ambang pintu pada pintu masuk utama telah direkabentuk rendah supaya seseorang tetamu itu menundukkan kepalanya sebelum masuk ke ruang serambi. Perilaku tersebut merupakan simbolik penghormatan tetamu kepada tuan rumah.
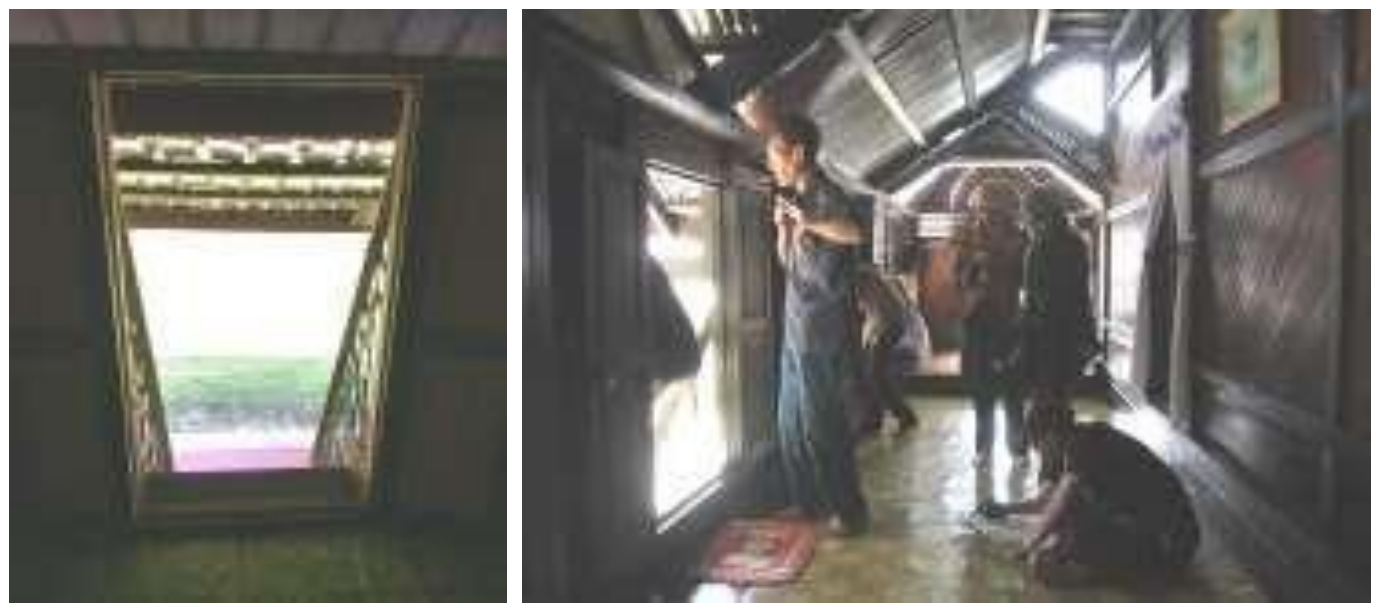

Gambar 3: Rekabentuk ambang pintu serambi RTMN9 yang rendah.

(Sumber: Penulis)

Selain itu, penggunaan elemen kekisi yang boleh ditembusi cahaya dan angin juga dipasang pada bahagian atas tingkap bagi membantu kelancaran pengudaraan dan pencahayaan pada ruang. Dengan adanya tingkap dan kekisi berukiran tebuk tembus di ruang serambi, maka ianya secara tidak langsung dapat mengekalkan semangat keterbukaan ruang tersebut. Motif ukiran flora yang menghiasi bahagian kekisi di atas tingkap, pintu, tiang rumah, papan dinding akan memberikan kesan kebersamaan dengan alam selain mempamerkan ciri-ciri dekorasi islamik pada ruang tersebut. Kuantiti penggunaan elemen ukiran di dalam ruang serambi adalah melambangkan status keluarga dan tahap ekonomi pemilik rumah (Nurdiyana, 2014). Bagi golongan yang berada atau berpangkat, kebiasaanya ruang serambi rumah padat dengan elemen ukiran manakala bagi rumah orang kebanyakan kebiasaanya terdapat sedikit atau tiada langsung penggunaan elemen ukiran dibuat pada ruang dalam serambi. 

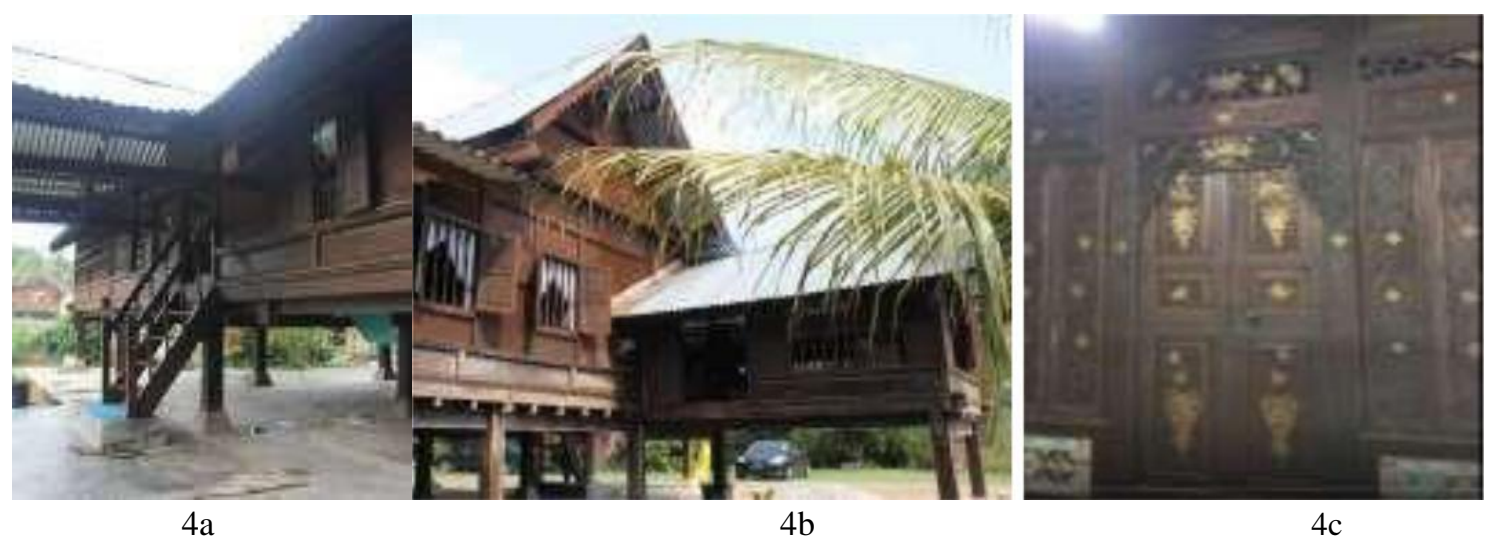

Gambar 4a dan 4b: Elemen bukaan di ruang serambi RTMN9.

Gambar 4c: Elemen ukiran pada dinding ruang dalam serambi RTMN9

(Sumber: KAWANS, Politeknik Port Dickson)

\section{PERANAN SERAMBI DALAM PERLAKSANAAN ADAT PERPATIH.}

Peranan ruang serambi rumah tradisional Melayu Negeri Sembilan dapat dilihat melalui dua aspek utama iaitu peranan terhadap perlaksanaan adat dan peranan terhadap budaya kehidupan seharian penghuni. Artikel ini akan memfokuskan perbincangan yang terperinci berkaitan peranan ruang serambi rumah tradisional Negeri Sembilan terhadap perlaksanaan Adat Perpatih yang berlangsung di ruang tersebut. Kepelbagaian fungsi ruang serambi rumah Melayu Negeri Sembilan dapat dihurai dan diperjelaskan melalui penerokaan amalan aktiviti Adat Perpatih oleh masyarakat di Negeri Sembilan di dalam ruang tersebut. Ruang serambi yang bersifat ruang tidak formal dalam kehidupan seharian penghuni telah ditransformasi menjadi sebuah ruang formal sewaktu acara adat berlangsung. Antara amalan sosial Adat Perpatih yang dilaksanakan di ruangan ini termasuklah adat merisik, bertunang lanang, adat nikah kahwin, adat menyalang, istiadat kerjan, istiadat kematian, adat menyandar, adat berkadim, adat berkhatan, adat memilih mata benih dan banyak lagi. Berdasarkan temubual yang dijalankan bersama responden, peranan ruang serambi terhadap perlaksanaan Adat Perpatih dapat digambarkan secara ringkas seperti rajah 2.

Rajah 2: Peranan Serambi Terhadap Perlaksanaan Aktiviti Adat Perpatih

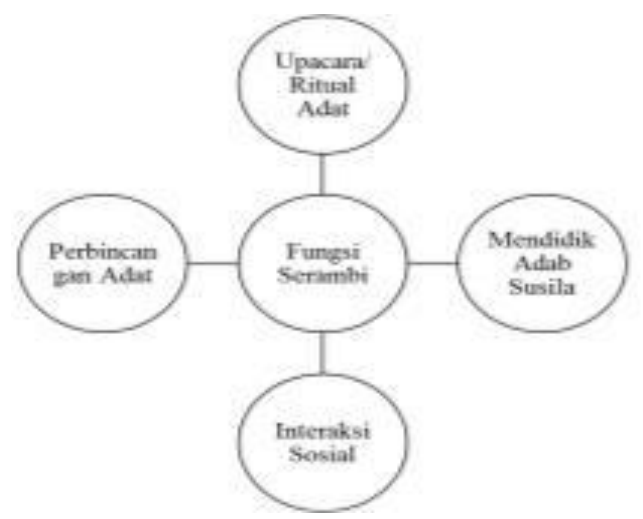

\section{RUANG PERBINCANGAN ADAT}

Berdasarkan pengalaman kesemua responden, bersetuju bahawa ruang serambi rumah tradisional Melayu Negeri Sembilan memainkan peranan yang penting sebagai sebuah ruang menjalankan perbincangan berkenaan adat sebelum atau sewaktu majlis aktiviti adat berlangsung. Aktiviti perbincangan adat dipanggil kerapatan adat oleh masyarakat Adat Perpatih. Peranan ruang serambi sebagai ruang perbincangan berkait dengan kata perbilangan adat yang telah diperturunkan iaitu; 'Pangkal untuk orang adat dan hujung untuk orang alim dan penghulu'

Kata perbilangan adat tersebut menjelaskan kedudukan orang adat di dalam ruangan serambi ketika mendirikan adat. Menurut ungkapan tersebut, orang adat yang dimaksudkan adalah ketua adat (buapak) iaitu kedudukan buapak sewaktu mendirikan adat adalah di zon pangkal serambi. Kesemua responden juga bersetuju menyatakan perbincangan berkenaan adat wajib dijalankan di ruang pangkal serambi kerana perbincangan berkaitan adat adalah melibatkan buapak. Buapak berperanan sebagai ketua dan pelaksana adat dalam perut lingkungannya. Buapak adalah individu yang akan dirujuk dalam segala permasalahan anak buah berkenaan perihal adat mahupun kehidupan seharian. Budaya bermuafakat merupakan tunjang kepada masyarakat Adat Perpatih. Segala bentuk aktiviti yang dirancang dan ingin dilaksana oleh anak buah di dalam suku perlulah dibincangkan bersama-sama buapak sehingga kebulatan atau kata putus dicapai.

Responden telah berkongsi pengalaman berkenaan salah satu adat yang diamalkan sewaktu perlaksanaan adat nikah kahwin di Negeri Sembilan yang melibatkan aktiviti kerapatan adat di dalam ruang serambi. 
‘... Dalam perlaksanaan adat nikah kahwin, masyarakat Adat Perpatih, adat berkampung merupakan salah satu aktiviti adat yang di laksanakan diruang serambi rumah. Adat ini dilaksanakan dalam dua peringkat sebelum berlangsungnya majlis pernikahan iaitu adat berkampung anak-beranak dan adat berkampung ramai. Adat berkampung anak beranak merupakan aktiviti perbincangan yang dilakukan oleh keluarga terdekat bersama buapak suku, bagi membincang berkenaan perlaksanaan majlis adat yang akan dilaksanakan termasuklah perkara asas seperti kemampuan kewaangan, tetamu jemputan, peralatan adat dan lain-lain. Tujuannya adalah untuk melancarkan perjalanan majlis perkahwinan yang akan berlangsung. Setelah kesepakatan dicapai, maka penentuan tarikh kayu berakar (persediaan majlis perkahwinan) akan ditetapkan. Sebelum majlis kayu berakar dilaksanakan, adat berkampung ramai pula akan dilaksanakan yang akan melibatkan anggota keluarga yang lebih besar bersama buapak bagi membincangkan isu yang berbangkit dan agihan kerja bagi menjayakan majlis. Konsep masyarakat Adat Perpatih adalah melaksanakan sebarang aktiviti secara bergotong-royong dan bantu-membantu satu sama lain dalam kalangan anggota suku. Adat berkampung dipimpin oleh buapak di ruang serambi. Buapak akan duduk di pangkal serambi dan akan menghadap ke arah semua anak buah yang hadir dan memulakan sesi perbincangan'...

Berdasarkan kenyataan responden, rekabentuk ruang serambi yang memanjang tanpa sebarang sekatan (open plan) membolehkan anak buah atau waris suku yang hadir duduk memanjang secara menghadap di antara satu sama lain bagi menjalankan musyawarah bersama. Konsep rekabentuk ruang serambi RTMN9 mempunyai persamaan dengan konsep rekabentuk ruang mesyuarat. Dalam situasi ini keseluruhan ruang serambi digunapakai bagi menjalankan perbincangan dan tidaklah tertumpu kepada ruang pangkal serambi sahaja. Konsep rekabentuk ruang serambi yang terbuka dengan banyak bukaan tingkap, pintu dan kekisi angin membolehkan perbincangan bersama anggota keluarga atau suku dilaksanakan dengan selesa dan nyaman berikutan mendapat pengudaraan dan pencahayaan yang baik berdasarkan rekabentuk tersebut. Situasi di atas jelas menunjukkan budaya berbincang merupakan salah satu bentuk muafakat yang menjadi teras dalam kehidupan masyarakat Adat Perpatih di Negeri Sembilan dan ruang serambi rumah pula telah dijadikan medan perlaksanaan atau ruang menjalankan aktiviti sosial tersebut. Kebijaksanaan masyarakat terdahulu dalam merekabentuk sesebuah ruang jelas terpancar apabila berjaya menghasilkan rekaan yang menepati kehendak adat, budaya hidup masyarakat pada zaman itu.

Rajah 3: Aturan ruang serambi sewaktu perlaksanaan Adat Berkampung.

(Sumber: Penulis)

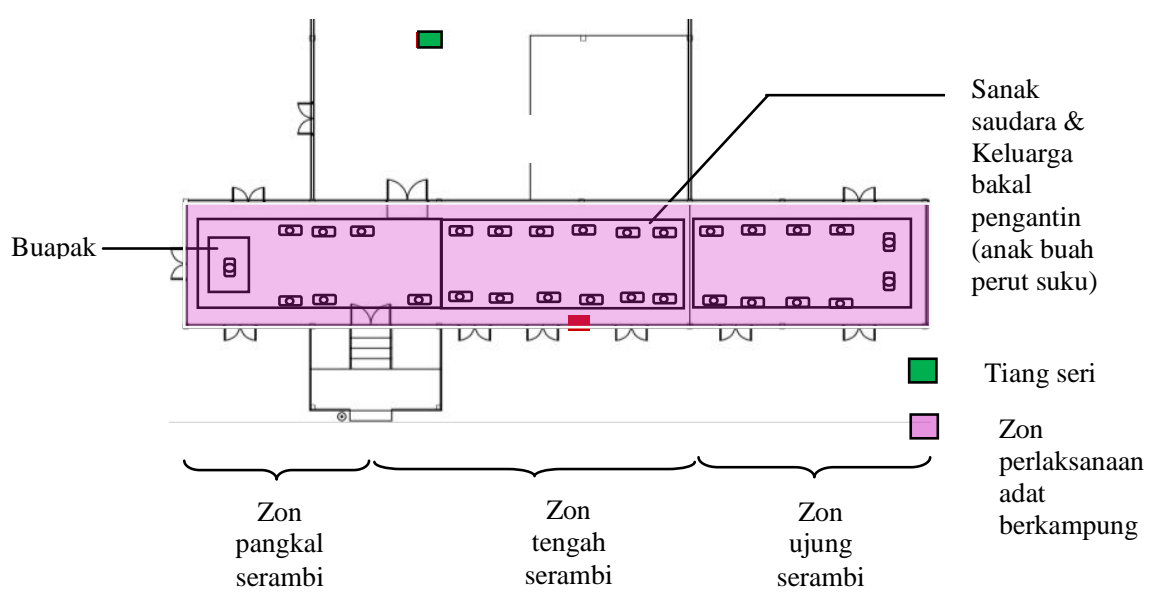

\section{RUANG RITUAL ADAT}

Amalan ritual adat adalah aturan-aturan yang diguna pakai oleh masyarakat adat sewaktu melaksanakan adat. Perlaksanaannya melambangkan perilaku tertentu dan bersifat formal serta dilakukan dalam waktu tertentu seperti yang dikehendaki adat (Koentjaraningrat, 1990). Perlaksanaan sesuatu upacara adat adalah tidak lengkap tanpa menjalankan upacara ritual adat. Menurut semua responden, ruang serambi merupakan ruang utama bagi menjalankan aktiviti ritual adat. Responden telah berkongsi pengalaman perlaksanaan ritual adat Berkadim Aur Serumpun di ruang serambi rumah tradisional di Negeri Sembilan. Adat Berkadim Aur Serumpun 
merupakan amalan tradisi masyarakat Melayu di Negeri Sembilan untuk mengambil anak angkat secara sah bagi tujuan mewarisi harta pusaka bagi pasangan suami isteri yang tiada anak perempuan. Masyarakat Melayu Negeri Sembilan berpegang kepada konsep matrilineal dalam kehidupan (Noor Hayati, Kamil. S \& Surat.M, 2016). Oleh itu, perwarisan harta pusaka adalah kepada anak perempuan sahaja. Anak lelaki tidak dibenarkan mewarisi harta pusaka tetapi dilantik sebagai penyandang pesaka (jawatan atau gelaran adat) (Norhalim. H. I, 2003). Adat berkadim ini dikhaskan untuk kaum perempuan sahaja dan dikenali juga sebagai berkadim adat dan pusaka. Menurut responden;

'...Majlis istiadat rasmi dilaksanakan di ruangan serambi rumah pusaka. Bagi adat berkadim, aktiviti ritual adat akan berlangsung di ruang serambi tengah. Peralatan adat seperti sebuah pantar (dulang) bertutup yang berisi semangkuk darah lembu atau kerbau (kini ditukar dengan pewarna merah disebabkan amalan menggunakan darah haiwan bertentangan dengan ajaran Islam), kain putih berukuran 2 meter, wang istiadat, surat pengesahan adat berkadim dan senaskah $\mathrm{Al}$ Quran akan diletakkan di zon serambi tengah tersebut. Sewaktu majlis berlangsung, buapak akan duduk di bahagian pangkal serambi bersama-sama buapak-buapak jemputan yang lain. Bahagian hujung serambi dikhaskan kepada pembesar adat iaitu datuk lembaga, imam, ketua kampung dan tetamu bergelar lain yang dijemput sama. Individu yang akan berkadim akan duduk bersama-sama ibu soko (perempuan tertua dalam perut suku) di ruangan rumah ibu, iaitu di tiang seri (tiang tengah) rumah terlebih dahulu sehinggalah dipanggil oleh tuo waris (lelaki tertua dalam perut suku) ke ruangan istiadat di serambi tengah bagi acara 'cecah darah' dan akujanji. Tetamu-tetamu dan waris-waris suku yang lain akan duduk memenuhi ruang diantara serambi pangkal dan hujung. Sebelum ritual adat berlangsung, tuo waris akan menerangkan kegunaan peralatan adat yang disediakan termasuklah duit istiadat, darah (cecair pewarna merah) dan kain sekabung yang terletak di dalam pantar. Setelah penerangan dibuat, buapak akan menyembahkan istiadat kepada lembaga bagi memperkenankan istiadat berkadim yang berlangsung. Selepas itu, acara cecah darah akan bermula dan ibu soko dan individu yang akan berkadim akan dipanggil ke ruang ritual (tengah serambi) bagi menyempurnakan acara adat. Ibu soko akan mengepilkan jari manisnya bersama jari manis individu yang berkadim, lalu dimasukkan bersama-sama ke dalam mangkuk berisi pewarna merah sebagai pengesahan mereka telah dikadimkan. Hal ini adalah simbolik bagi membuktikan hubungan individu yang dikadimkan tersebut telah sedarah dengan ibu soko dan keturunannya. Datuk lembaga akan menyerahkan surat pengesahan istiadat lengkap bertandatangan beserta cop rasmi kepada saksi- saksi iaitu lembaga, buapak, ibu soko dan individu berkadim untuk simpanan. Setelah itu, ibu soko dan anak angkatnya akan kembali ke ruangan rumah ibu semula untuk menyertai tetamu wanita yang lain.

Situasi perlaksanaan upacara adat yang dihuraikan jelas menunjukkan ruang serambi memainkan peranan yang sangat besar terutamanya dalam perlaksanaan aktiviti ritual adat. Zon serambi tengah merupakan zon yang sangat penting sewaktu acara ritual adat berkadim berlangsung di mana sebahagian besar aktiviti ritual telah berlangsung di ruangan ini. Berdasarkan pemerhatian pengkaji, zon serambi tengah digunakan sebagai ruang perlaksanaan aktiviti ritual adat adalah disebabkan factor kedudukannya yang berada di tengah-tengah diantara ruang yang menempatkan pembesar adat (hujung) dan pelaksana adat (pangkal) yang mana' kedudukan tetamu pada zon tersebut mempunyai kelebihan pemandangan yang jelas terhadap perlaksanaan aktiviti ritual di zon tersebut. Selain itu, kedudukan zon yang berhampiran dengan pintu masuk utama ke rumah ibu yang menempatkan kaum wanita, memberi peluang kepada kaum wanita bersama-sama menyaksikan acara kemuncak perlaksanaan majlis adat di ruang tersebut. Walau bagaimanapun menurut responden, lokasi dan cara perlaksanaan aktiviti ritual adat di dalam ruang serambi adalah berbeza bergantung kepada jenis upacara atau majlis adat yang berlangsung. Jadual 1 menunjukkan beberapa jenis adat yang berlangsung di ruang serambi RTMN9 dan lokasi perlaksanaan aktiviti ritual adat yang dijalakan di dalam ruangtersebut.

Jadual 1: Lokasi perlaksanaan aktiviti ritual adat di ruang serambi RTMN9 


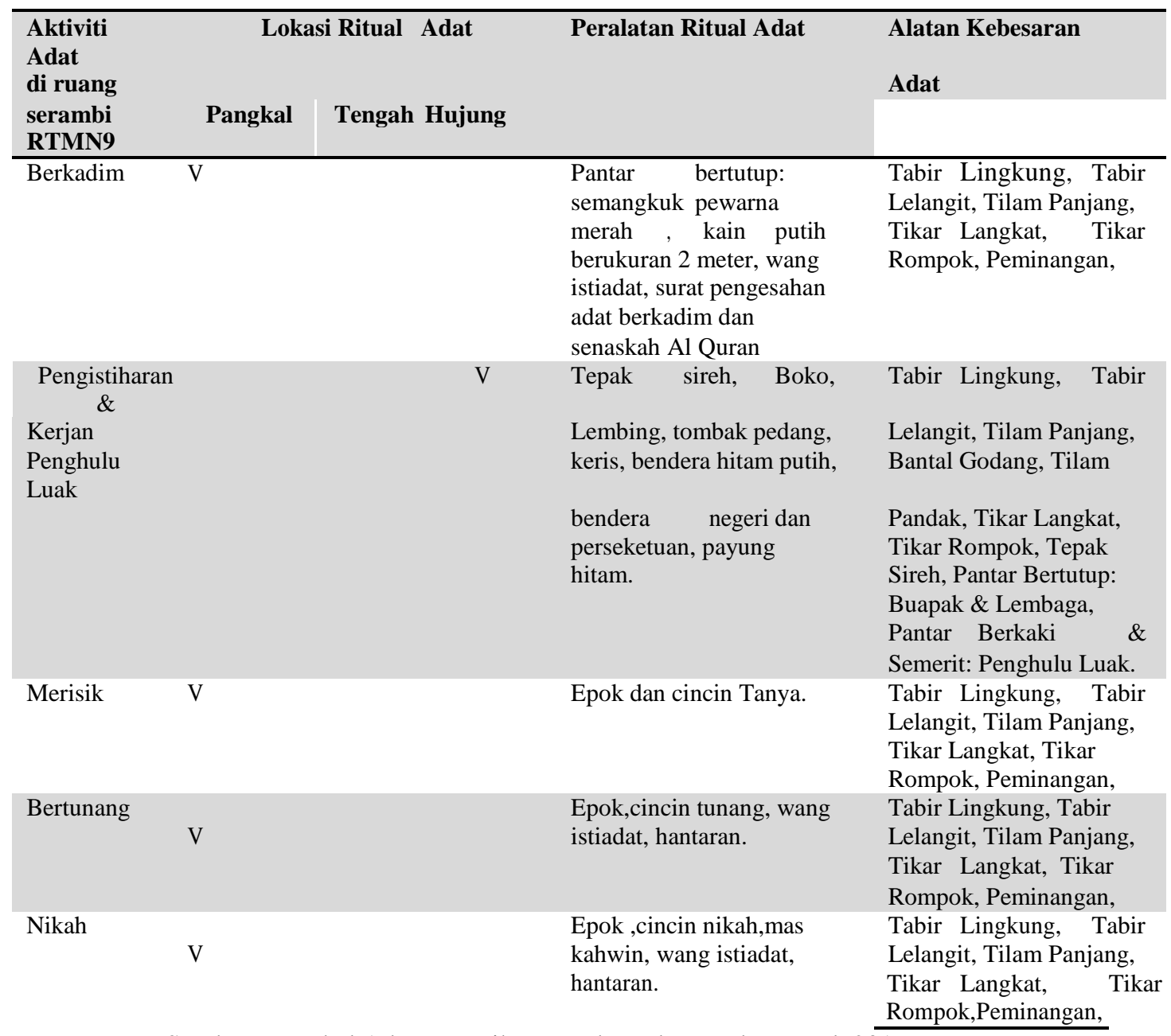

Sumber: Bengkel Adat Perpatih, Teratak Zaaba, Luak Jempol. 2016.

Berdasarkan jadual di atas, menunjukkan kebanyakan aktiviti ritual adat berlangsung di ruang serambi tengah. Walaubagaimapun, lokasi perlaksanaan aktiviti ritual adat adalah tidak sama bagi setiap aktiviti adat yang didirikan. Sebagai contoh, acara ritual adat Pengistiharan dan Kerjan Penghulu Luak dilaksanakan di bahagian serambi hujung kerana acara ritual adalah melibatkan aktiviti 'sembah hormat' anak buah kepada Penghulu Luak. Oleh kerana kedudukan Penghulu Luak adalah di bahagian serambi hujung balai ketika majlis adat, maka aktiviti 'sembah hormat' dilaksanakan di ruang tersebut. Seperti yang dikongsi oleh responden;

'...Dato'Penghulu Luak akan diarak ke balai dengan dipayungi oleh Dato' Maharaja Setia dan diiringi oleh Dato'- Dato' Lembaga dan Ibu Soko. Setelah sampai, rombongan disambut oleh Dato'Sri Amar Menteri di tangga balai dan mengiringi Dato' Penghulu Luak ke tempat duduknya di hujung serambi balai. Ketika itu, Dato'-dato Lembaga dan orang-orang kenamaan yang lain telahpun sedia menunggu di balai. Setelah semua mengambil kedudukan masing-masing, istiadat angkat sembah akan dimulakan dengan Dato'- Dato’ Lembaga kanan, Dato'- Dato' Lembaga, buapak-buapak, anak-anak buah serta Ibu Soko. Istiadat kerjan diakhiri dengan bacaan doa oleh Pegawai Agama Daerah'...

Berdasarkan Jadual 1, didapati peralatan adat untuk kegunaan acara ritual juga adalah berlainan bergantung kepada majlis adat yang berlangsung. Walaubagaimanapun perkara asas yang wajib dilaksanakan bagi semua jenis upacara adat di dalam ruang serambi adalah pemasangan alatan kebesaran adat di dalam ruang serambi bagi menandakan majlis adat sedang berlangsung.

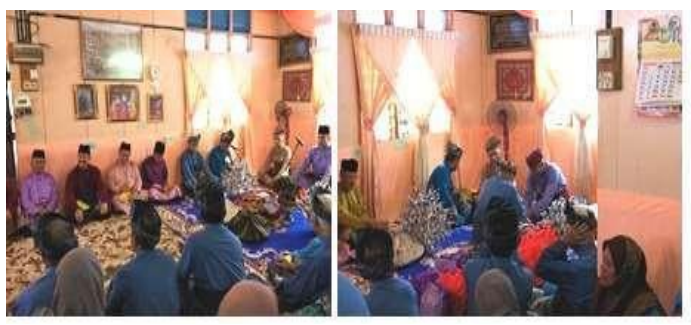

Gambar 5: Acara sembah hormat Adat Pengistiharan Penghulu Luak Jempol di serambi hujung. (Sumber: Penulis) 


\section{RUANG SOSIAL}

Ruang sosial pada pandangan ahli sosiologi adalah tempat di mana masyarakat berkumpul dan berinteraksi antara satu sama lain tanpa ada sekatan atau halangan terhadap kedua-dua pihak menjalankan proses interaksi (Gans, 2002). Bagi masyarakat Adat Perpatih di Negeri Sembilan, ruang serambi rumah direkabentuk sebagai sebuah ruang sosial bagi penghuni menjalinkan hubungan dan berinteraksi dengan masyarakat sekeliling serta menjalankan aktiviti adat. Peranan ruang serambi sebagai sebuah ruang sosial masyarakat adat dapat diperjelaskan melalui beberapa situasi perlaksanaan akiviti adat di ruang tersebut seperti sewaktu perlaksanaan adat menjemput ketua atau pembesar adat ke majlis adat dan adat merisik seperti yang dikongsi oleh responden-responden melalui temubual yang di jalankan. Responden telah berkongsi pengalaman mengendalikan adat merisik iaitu salah satu aktiviti adat bagi perlaksanaan adat nikah kahwin masyarakat adat di Negeri Sembilan di dalam ruang serambi rumah.

'...Adat merisik adalah usaha yang dijalankan oleh orang semenda (lelaki yang berkahwin dengan anggota sesuatu suku) untuk mencari calon untuk dijadikan menantu. Upacara merisik akan dilaksanakan oleh pihak lelaki kepada pihak perempuan melalui monti (orang perantaraan). Seterusnya monti akan berjumpa dengan ibubapa perempuan dengan membawa sebentuk cincin tanya dan epok. Upacara merisik tersebut akan berlaku di serambi rumah iaitu di zon serambi pangkal atau tengah. Monti berkunjung ke rumah pihak perempuan bagi merisik status diri, latar belakang dan asal usul perempuan yang hendak disunting. Pelbagai pertanyaan dan persoalan akan diajukan oleh monti kepada pihak perempuan bagi mendapatkan maklumat berkenaan perempuan yang hendak dilamar. Setelah cincin diterima oleh pihak perempuan, ia hendaklah dikembang (diberitahu) kepada waris sekodim, iaitu saudara terdekat. Tempoh untuk mendapat jawapan sama ada setuju atau tidak dari waris sekodim itu adalah tidak tetap dan ada yang menjangkau masa berbulan-bulan lamanya. Sekiranya mendapat keputusan sama ada bersetuju ataupun tidak, maka akan dikhabarkan oleh pihak perempuan kepada pihak lelaki. Keputusan tersebut disampaikan secara berhemah seperti yang diungkap dalam perbilangan adat: "Oso sekato, kato dikembalikan, tak oso sekato, tando dikembalikan". Jika sekiranya telah "oso sekato" atau bersetuju, maka majlis pertunangan akan dilangsungkan...'

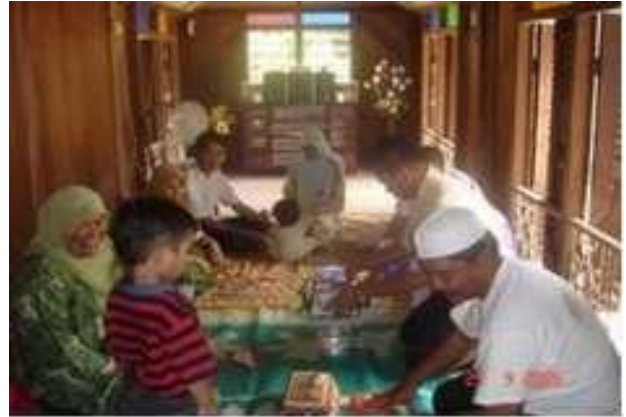

Gambar 6: Adat Merisik di ruang serambi.

(Sumber:https://mforum.cari.com.my/forum.php ?mod=viewthread\&tid=314439, semakan pada 27 Disember 2016)

Peranan serambi sebagai ruang sosial juga dapat dilihat sewaktu perlaksanaan adat menjemput ketua atau pembesar adat bagi sesuatu majlis adat. Responden juga berkongsi pengalaman perlaksanaan adat menjemput yang di laksanakan di ruang serambi rumah;

'...Sewaktu datang menjemput, ruang serambi merupakan ruang yang menjadi tumpuan utama tetamu yang berkunjung. Anak buah atau tetamu kebiasaanya akan dipelawa ke serambi tengah atau pangkal oleh tuan rumah. Sewaktu anak buah datang berkunjung, mereka akan membawa bersama epok iaitu bekas berisi sireh untuk diserahkan kepada ketua adat atu pembesar adat. Sambil bersalaman dan menyerahkan epok, anak buah akan menyuarakan hajat menjemput secara formal seperti “....saya To' Panglima Garang hendak menjemput Dato' Shahbandar hadir ke majlis pernikahan anak saya pada...". Membawa epok atau bujam sewaktu menjemput adalah satu kewajiban adat. Sireh dan pinang adalah dianggap sebagai pembuka kata dan tanda mendirikan adat'

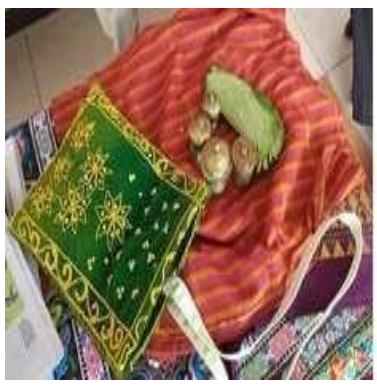

$7 \mathrm{a}$

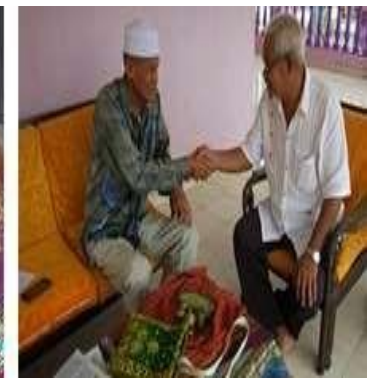

$7 \mathrm{~b}$
Gambar 7a: Bekas Epok

Gambar 7b: Adat Menjemput.

(Sumber: Pengkaji) 
Berdasarkan kedua-dua situasi yang dikongsi oleh responden, mereka bersetuju menyatakan peranan ruang serambi adalah sangat besar sebagai sebuah ruang sosial bagi masyarakat Adat Perpatih. Ini adalah kerana aktiviti yang melibatkan perlaksanaan adat akan mewujudkan interaksi sosial dalam kalangan masyarakat adat bagi menjayakan aktiviti adat yang dirancang. Faktor kedudukan ruang serambi yang terletak di bahagian paling hadapan rumah, menjadikannya sebagai ruang yang paling ideal bagi menerima kunjungan tetamu berbanding ruang-ruang lain yang berada di bahagian belakang. Oleh itu, kehadiran tetamu tidaklah mengganggu privasi penghuni rumah yang lain terutama yang berada di ruangan rumah ibu. Zon pangkal dan tengah serambi pula merupakan zon utama yang digunakan bagi menjalankan aktiviti sosial penghuni dengan masyarakat luar. Tetamu dipelawa ke ruangan pangkal atau tengah serambi untuk beramah-mesra, menyampaikan hajat, menjalinkan ikatan silaturahim, mengadakan perbincangan ataupun bersama-sama menjayakan aktiviti adat. Penggunaan ruang diperluaskan sehingga ke hujung serambi bergantung kepada saiz bilangan tetamu yang berkunjung. Selain itu, kedudukan pangkal dan tengah serambi yang berhampiran dengan tangga dan pintu masuk utama, menjadikan ruangan ini sebagai zon yang paling sesuai untuk menerima kunjungan tetamu. Oleh itu, telah terbukti bahawa ruang serambi yang telah dicipta oleh masyarakat Melayu pada zaman dahulu adalah sebuah ruang social yang menghubungkan penghuni ruang dengan masyarakat sekeliling dengan bertindak sebagai ruang beramah mesra, mengadakan pertemuan, perbincangan serta menjalankan aktiviti-aktiviti adat bagi mengukuhkan ikatan tali persaudaraan sesama manusia.

Rajah 4: Ruang sosial pemilik rumah dan tetamu di ruangan serambi.(Sumber: Penulis)

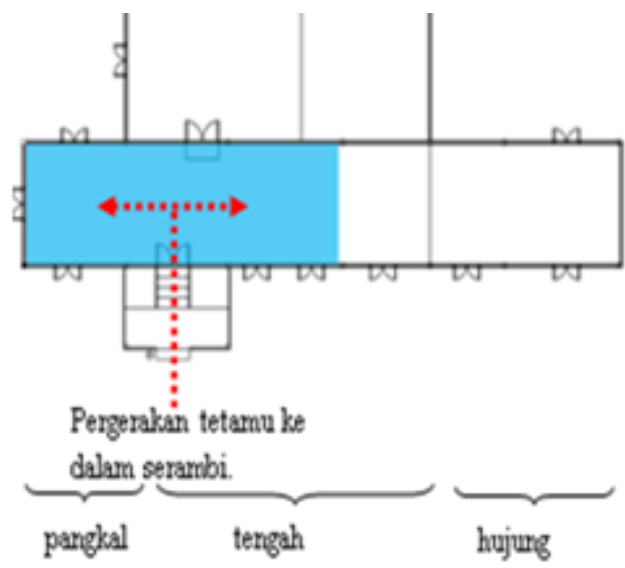

\section{PENDIDIKAN ADAB}

Masyarakat Melayu terdahulu sangat menitikberat tentang penjagaan adab dan susila dalam kehidupan seharian. Bersopan santun dan berbudi pekerti adalah sebahagian daripada nilai-nilai tamadun Melayu yang berkaitan dengan peradaban. Masyarakat Melayu menganggap bahawa orang yang beradab sebagai seorang yang halus budi pekerti, manakala yang tidak beradab dianggap kasar. Adab dapat didefinisi sebagai tingkah laku serta tutur kata yang sopan, berbudi bahasa serta mempunyai kehalusan dan kebaikan budi pekerti. Kesemua ini mempunyai kaitan dengan pendidikan dan etika manusia (Zurakintan Abdul Razak \& Che Ibrahim Salleh, 2015). Masyarakat yang mengamalkan peradaban merupakan masyarakat yang telah maju dan bertamadun serta dapat membezakan kebaikan dan keburukan. Islam juga menuntut manusia agar sentiasa menjaga adab dan tatasusila dalam kehidupan.

Bagi masyarakat adat di Negeri Sembilan, ruang serambi rumah kediaman memainkan peranan yang besar sebagai ruang pendidikan adab susila masyarakat yang dapat dilihat sewaktu perlaksanaan aktiviti Adat Perpatih. Menurut kenyataan responden,

...'sewaktu majlis adat, zon serambi hujung adalah dikhaskan kepada pembesar adat, tetamu bergelar, pegawai kerajaan dan orang alim manakala zon pangkal serambi adalah dikhas kepada ketua adat. Tetamu lelaki lain akan memenuhi ruang tengah. Mereka akan masuk melalui pintu utama rumah. Kedua-dua zon serambi pangkal dan hujung perlu dihias dan dilengkapi dengan alatan kebesaran adat. Hujung dan pangkal serambi akan dipasang dengan tabir langitlangit di bahagian bawah bumbung dan tabir lingkung di sekeliling dinding. Kain yang digunakan kebiasaannya adalah kain bewarnawarni. Bahagian lantai di kedua-dua zon perlu dialas dengan tikar rompok dan tikar langkat dan diletakkan peminangan. Peminangan adalah bekas berisi sireh dan pinang yang perlu disediakan sewaktu mendirikan adat'...

Berdasarkan kenyataan responden, kedudukan pembesar adat dan tetamu bergelar adalah di ruang serambi hujung sewaktu majlis adat berlangsung. Faktor kedudukannya di bahagian hujung rumah menjadikan ruang tersebut bersifat lebih privasi dan dapat mengelak daripada sebarang perlakuan kurang sopan tetamu seperti bergerak atau melintas di hadapan tetamu terhormat. Aturan ruang yang dicipta telah menzahirkan budaya menghormati dan memuliakan ketua dalam 
kalangan anak buah kepada ketua dan pembesar mereka. Zon serambi hujung dan pangkal juga dihiasi dengan alatan kebesaran adat seperti tabir langit-langit, tabir lingkung, tikar rompok, tikar langkat dan diletakkan peminangan pula adalah sebagai tanda meraikan ketua oleh anak buah selain sebagai kewajiban dalam mendirikan adat. Seperti kata perbilangan adat;

'sudah ampak rupanya tabir, sudah terbentang langit-langit, sudah tersedia tepak sireh, sudah terbentang tikar rompok, bak kata adat, hukum tak menghambat, adat tidak menghalang'

Secara falsafahnya, pemasangan tabir langitlangit di ruang serambi adalah untuk menghalang sebarang kekotoran seperti habuk daripada bahagian atas rumah terkena pada tetamu selain bertindak sebagai 'payung' kepada pembesar adat (Lembaga \& Penghulu
Luak) sewaktu berada di ruangan tersebut (Othman Mohd Nor et. Al, 2014). Tabir lingkung pula dipasang di sekeliling diding zon hujung serambi dan pangkal serambi bagi mewujudkan suasana yang lebih privasi di ruang tersebut. Pemasangan kain tabir di keduadua zon serambi ini menandakan kawasan tersebut merupakan kawasan khas bagi orang yang berkedudukan di dalam adat. Oleh itu, ruang tersebut perlu dihiasi dan dirapi sebaik mungkin supaya kelihatan menarik, kemas, bersih dan selesa. Selain aturan ruang, rekabentuk pintu masuk utama ke ruang serambi yang dibina rendah juga telah menghasilkan satu ketertiban perilaku pengguna ruang iaitu tetamu perlu menundukkan kepala sewaktu hendak masuk ke dalam rumah yang melambangkan penghormatan tetamu kepada tuan rumah selain melahirkan sifat sopan santun dalam kalangan masyarakat.

Rajah 5: Ruang khas pembesar adat di serambi hujung.(Sumber: Penulis)

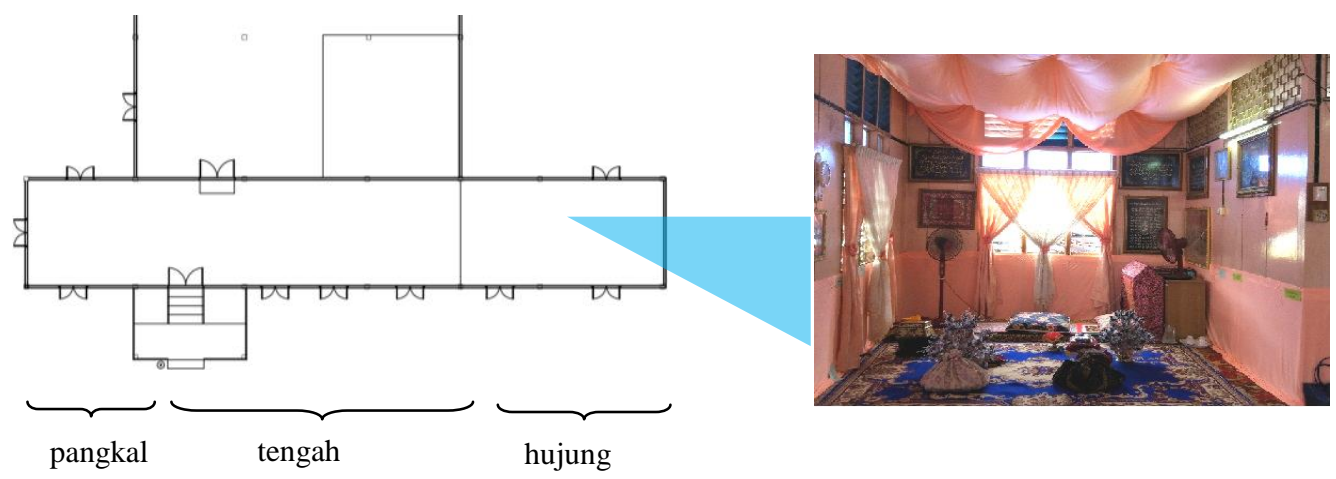

Menurut responden, peranan ruang serambi sebagai ruang pendidikan adab sewaktu perlaksanaan acara Adat perpatih bagi masyarakat di Negeri Sembilan j ga dapat diperjelaskan melalui contoh situasi perlaksanaan adat makan berselo yang diamalkan oleh masyrakat adat.

'...adat makan berselo wajib dilaksanakan sejurus tamat perlaksanaan majlis adat di ruang serambi. Budaya makan berselo adalah tradisi yang diamalkan oleh masyarakat adat ketika bertemu dengan pengamal Adat Perpatih yang berkuasa seperti, buapak, lembaga, penghulu atau undang. Aktiviti makan berselo dilaksanakan di ruang serambi rumah bagi tetamu lelaki manakala ruang rumah ibu dan dapur bagi tetamu wanita. Pangkal serambi merupakan ruang khas bagi buapak dan ujung serambi pula adalah ruang khas untuk lembaga atau penghulu luak menikmati hidangan. Hidangan istimewa akan disajikan di dalam pantar (dulang) bertutup dengan tudung saji serta peralatan sajian seperti pinggan dan cawan perlu beralas bagi hidangan buapak dan lembaga. Hidangan paling istimewa kebiasaannya adalah masakan kepala kambing. Bagi tetamu lain, hidangan hanyalah sekadar diletakkan di dalam pantar tanpa penutup Hidangan terdiri daripada masakan-masakan selain daripada masakan istimewa'...

Berdasarkan kenyataan responden, aktiviti makan berselo adalah budaya yang diamalkan oleh masyarakat adat di Negeri Sembilan bagi meraikan tetamu yang hadir dalam majlis adat yang dianjurkan oleh tuan rumah. Kehadiran tetamu sentiasa dipandang mulia oleh masyarakat adat dan perlu diraikan dengan sebaik-baiknya. Ruang serambi yang berfungsi sebagai ruang perlaksanaan upacara adat sebelumnya telah ditranformasikan fungsinya sebagai ruang makan bagi meraikan tetamu yang hadir ke majlis tersebut. Ruang serambi dikhususkan kepada kaum lelaki manakala ruang rumah ibu dan dapur adalah ruang bagi kaum wanita menikmati hidangan. Pengasingan ruang antara kaum lelaki dan wanita dalam rumah tradisional melambangkan konsep moral yang tinggi wujud dalam kalangan masyarakat adat selaras dengan kehendak hukum syarak yang 
melarang pergaulan bebas antara kaum lelaki dan wanita yang bukan muhrim. Selain itu, penyediaan hidangan dan penggunaan kelengkapan khas bagi tetamu istimewa seperti buapak, lembaga dan penghulu luak sewaktu adat makan berselo berlangsung adalah sebagai simbol penghormatan dan penghargaan anak buah terhadap ketua mereka dalam memimpin adat.
Situasi-situasi yang diperbincang jelas mengambarkan bagaimana ruang serambi berperanan mendidik rohani dan sahsiah masyarakat Melayu di Negeri Sembilan. Rekabentuk dan aturan zon-zon di ruang serambi telah menyumbang kepada penghasilan suatu karektor ketertiban perilaku budaya Melayu yang indah dan mematuhi syariat serta kehendak adat di dalam diri pengguna ruang sepanjang keberadaan mereka di ruangan tersebut ketika aktiviti adat berlangsung.

Rajah 6: Pengasingan ruang antara lelaki dan wanita sewaktu menjalankan aktiviti adat.

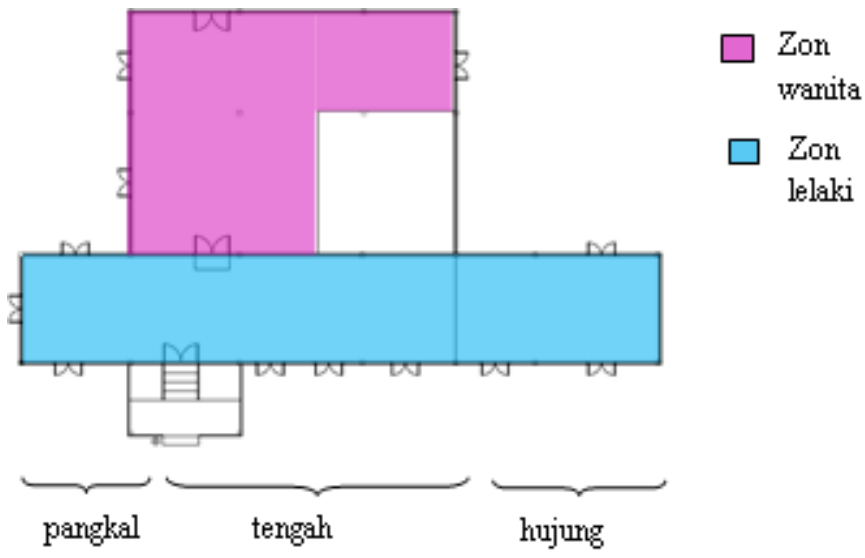

\section{KESIMPULAN}

Kesimpulannya, peranan serambi rumah tradisional Melayu Negeri Sembilan begitu menyeluruh meliputi cara hidup seharian penghuninya hinggalah berlangsungnya upacara adat. Peranan serambi sebagai ruang kaum lelaki begitu berkait rapat dengan sifat seorang lelaki yang mempunyai tanggungjawab berat untuk menjaga keluarga dan adatnya. Tanpa serambi, boleh dikatakan bahawa Adat Perpatih tidak mampu untuk dimartabatkan. Kehebatan ruang serambi rumah Melayu Negeri Sembilan yang dibincangkan ialah sifat serbagunanya yang mampu berfungsi dalam acara formal mahupun tidak formal tanpa sebarang pengubahsuaian terhadap struktur asalnya. Kewujudan adat dan ruang serambi merupakan sebuah jalinan rapat yang saling memerlukan serta lengkap melengkapi di antara satu sama lain. Selain berperanan sebagai ruang perbincangan dan perlaksanaan upacara ritual adat, ruang ini juga berperanan sebagai sebuah ruang sosial yang menyatukan masyarakat adat di Negeri Sembilan. Kehebatan konsep rekabentuk ruang serambi juga secara tidak langsung telah berjaya mendidik adab susila masyarakat adat dengan mencerminkan identiti dan budaya masyarakatnya yang hidup bermuafakat, hormat menghormati, berbudi bahasa, bersopan santun, menghargai tetamu dan mempunyai sahsiah yang terpuji. Hal ini melambangkan kebijaksanaan masyarakat Melayu merekabentuk ruang yang pada zahirnya kelihatan ringkas namun mencakupi seluruh aspek kehidupan berbudaya yang luas dan rumit.

Seharusnya perekabentuk rumah kediaman pada masa kini mencontohi kehebatan pemikiran masyarakat terdahulu dalam menghasilkan rekaan rumah kediaman yang berlandaskan adat dan budaya masyarakat timur yang penuh kesopanan serta memenuhi tuntutan syarak. Berdasarkan kajian, dapat di rumuskan bahawa, bagi menghasilkan sebuah rekaan ruang rumah kediaman yang terbaik dan berfungsi mengikut acuan budaya kebangsaan, faktor-faktor seperti nilai sosio-budaya, keagamaan, amalan adat, latar belakang ekonomi masyarakat serta iklim persekitaran perlu diberi perhatian, difahami dan diselami setiap satunya oleh para professional dan perekabentuk sebelum menghasilkan sesebuah rekaan. Sebagai contoh, konsep rekabentuk ruang serambi rumah Melayu tradisional Negeri Sembilan ciptaan masyarakat terdahulu boleh di jadikan inspirasi kepada rekabentuk 'ruang tamu' rumah moden pada masa kini iaitu dengan menerapkan pendekatan rekabentuk ruang yang mampu mengawal batasan sosial penghuni rumah kediaman khususnya di antara golongan lelaki dan wanita seperti yang telah diperbincangkan supaya isu sosial dalam konteks seni bina yang timbul dapat diatasi dengan kadar segera. Selain itu, kebijaksanaan susun atur ruang terutamanya terhadap penetapan zon-zon publik, dan privasi pada ruang-ruang dalam rumah kediaman bagi masyarakat terdahulu juga boleh dijadikan panduan pada rekabentuk moden masa kini bagi 
menjamin privasi penghuni di dalam rumah kediaman terpelihara waima ketika berlangsungnya aktiviti-aktiviti sosio-budaya di dalam rumah. Diharap dengan adanya penulisan artikel ini, intipatinya dapat membuka mata golongan professional menghayati bagaimana ruang dalam rumah Melayu tradisi khususnya ruang serambi membina makna pada kehidupan penghuninya dan memberi idea penghasilan rekabentuk perumahan moden yang mencerminkan identity dan budaya kebangsaan pada masa hadapan.

\section{RUJUKAN}

Afizi, K., \& Lukman, N. (2007), Identiti Seni Bina Malaysia: Masalah dan Penyelesaiannya Masalah dan Penyelesaiannya.Sari 25 (2007). UKM. 279-290.

Afizi, K., (2009), Krisis Wacana Identiti Seni Bina Malaysia. Bangi. UKM.

Chen, Y., Ariffin, S. I., \& Wang, M. (2008). The Typological Rule System of Malay Houses in Peninsula Malaysia. Journal of Asian Architecture and Building Engineering, $7(2), 247-254$.

https://doi.org/10.3130/jaabe.7.247.

Creswell, J.W. (2009). Research Design Third Edition. SAGE Publications.173- 201.

Gans, H. J. (2002). The Sociology of Space: A Use-Centered View. City and Community.1(4),329339.https://doi.org/10.1111/15406040.000 27.

Hardono, S., Azizi, A., \& Zarifah. (2014). Rumah Tradisional Negeri Sembilan: Susun Atur Ruang Dalaman dan Organisasi Kepimpinan kekerabatan Matrilineal Adat Perpatih, Prosiding Simposium Antarabangsa Muafakat Minang. UTM. 227-243.

Idrus, Y., (1996). Rumah Tradisional Negeri Sembilan: Satu Analisis Seni Bina Melayu. Fajar Bakti Sdn. Bhd. 52-55.

Idrus, Y. Ibid. 22-23.

Ismail,Z., \& Utaberta.N.

Kepentingan Identiti Tradisional Melayu Dalam Rekabentuk Perumahan Moden Di Malaysia. UPM, Serdang.

Koentjaraningrat.(1990). Pengantar Ilmu Antropologi. Jakarta: Rineka Cipta.

Masri, M., Rodzyah, M. Y., Sabarinah, S. A. (2016). The serambi: Inculcation of sociocultural Values in Malay Traditional Home Design. AMER International Conference on Quality of LifE, AicQoL (2016) Medan. Social and Behavioral Sciences 234. Elsivier Ltd. 255-264.

M.S.Surat., Usman, I.M.S., Tahir, M.M., Abdul H.I., N.L. Nik Ibrahim (2009). Pendekatan Dasar Pemikiran Seni Bina Warisan
Melayu Bagi Mendapatkan Keselesaan Hawa Serta Penyelesaian Masalah Iklim Dan Persekitaran Dalam Seni Bina Masa Kini. Journal Design + Built, Volume 2. UKM. 18-27.

M.S.Surat, M.A. Baharum, I.M.S Usman, A.R Musa, N.M.Tawil. (2012). Mengenalpasti Tahap Kesejahteraan Seni Bina Warisan Melayu Melalui Konsep Islam. Journal Design + Built, Volume 5, 2012.

Nafida, R., (1999). Evolusi Seni Bina Balai Adat di Negeri Sembilan, Universiti

Malaya, Kuala Lumpur. Tesis Master.

Noor, H., Kamil, S., \& Surat.M., (2016). Rekabentuk Rumah Tradisional Negeri Sembilan dipengaruhi Adat dan Kedaerahan. Wacana Seni Journal of Arts Discourse, 15:113136. http:dx.doi.org/10.21315/ws2016.15.5

Norhalim, H. I., (2003). Glosari Adat Negeri Sembilan. AFY Communications Shah Alam. 208.

Nurdiyana,. Z. A., Nafida,R., Fawazul.K., (2014), Woodcarving Placements in Traditional Malay Houses Of The Journal of Design and Built Environment Vol. 17 (2), December 2017 Siti Fatimah.T.et al. Wealthy And The Commoners Of Negeri Sembilan. Prosiding Simposium Antarabangsa Muafakat Minang. UTM. 325-330.

Othman ,M. N., Nafida, R., Norfazillah, N. \& Haryati (2014). Peranan Ruang Serambi Dalam Adat Perpatih \& Seni Bina Rumah Bumbung Panjang Negeri Sembilan. Prosiding Simposium Antarabangsa Muafakat Minang. UTM. 311-324.

Rahman. A.A., (2000). Petua Membina Rumah Melayu. Perpustakaan Negara Malaysia Kuala Lumpur.

Salleh. M (1982). Rumah Melayu Melaka: Jurnal Budaya Melayu, Jabatan Persuratan Melayu, UKM, Jilid5.190-198.

Zahra K.Z \& Sayedah M.T (2016).Comparative Study of Privacy in Designing Qajar Dynasty Isfahan's House and Malaysia's Traditional Houses. Journal of Design and Build Environment [S.1.], oct. 2016. ISSN 22321500.https://ejournal.um.edu.my/inde x.p hp/jdbe/article/view/5371>.

Zin, M. H. M., Ibrahim, N. L. N., Zain, M. F.M.,\& Jamil, M. (2012). The Social and Environmental Roles of Verandah in Tropical Houses. World Academy of Science, Engineering and Technology 68 2012, 6(8). 1702-1704.

Zurakintan, A.R., \& Che, I.S., (2015). Pemikiran Melayu tentang Ilmu dan Adab dalam Puisi Melayu. International Journal of the Malay World and Civilisation Iman 3(2). UKM. 121-129. 